\title{
Identification of the Plasmodium species in clinical samples from children residing in five epidemiological strata of malaria in Cameroon
}

\author{
Tebit Emmanuel Kwenti ${ }^{1,2,3^{*}}$, Tayong Dizzle Bita Kwenti ${ }^{2}$, Longdoh Anna Njunda ${ }^{1}$, Andreas Latz ${ }^{4}$, \\ Kukwah Anthony Tufon ${ }^{2}$ and Theresa Nkuo-Akenji ${ }^{2}$
}

\begin{abstract}
Background: Malaria in Cameroon was previously known to be caused solely by Plasmodium falciparum but today, evidence points to other Plasmodium species including $P$. vivax, $P$. ovale and $P$. malariae. The purpose of this study was to identify the Plasmodium species in clinical samples from children residing in five epidemiological strata of malaria in Cameroon, so as to advise control policies.

Methods: One thousand six hundred nine febrile children ( $\leq 15$ years) were recruited from five epidemiological strata of malaria including the Sudano-sahelian (SS) strata, the High inland plateau (HIP) strata, the South Cameroonian Equatorial forest (SCEF) strata, the High western plateau (HWP) strata and the Coastal (C) strata. Malaria parasites were detected by Giemsa microscopy (GM) while a multiplex polymerase chain reaction (PCR) was used to identify the Plasmodium species. Statistical analysis performed included the Pearson chi-square test, and statistical significance was set at $p<0.05$

Results: The PCR-adjusted prevalence of malaria was $17.6 \%$. The detection rate of PCR was higher than GM $(p=0.05)$. However, GM demonstrated a high sensitivity (85.5\%) and specificity (100\%) and, overall, a perfectly correlated agreement with PCR (97.5\%). The prevalence of malaria was significantly higher in children between 60 and 119 months $(p<0.001)$ and in Limbe (in the Coastal strata) $(p<0.001)$. Contrariwise, the prevalence of malaria was not associated with gender ( $p$ $=0.239)$. $P$. falciparum was identified in all (100\%) the cases of malaria; $P$. ovale, P. vivax, P. malariae and $P$. knowlesi were all absent. No case of mixed infection was identified.
\end{abstract}

Conclusions: P. falciparum was the only species causing clinical malaria in the target population, which is contrary to studies that have reported P. vivax, P. malariae and P. ovale as causing clinical malaria in Cameroon.

Keywords: Plasmodium species, PCR, Microscopy, Malaria, Children, Epidemiological strata, Cameroon

\section{Background}

Malaria remains a significant public health problem in many countries of the world especially in sub-Saharan Africa (SSA). The WHO estimates that in 2015, there were 214 million cases of malaria and 438,000 deaths attributed to malaria [1]. The majority $(90 \%)$ of cases and

\footnotetext{
* Correspondence: kwentitebit@yahoo.com

'Department of Medical Laboratory Sciences, University of Buea, P.B. 63, Buea, Cameroon

${ }^{2}$ Department of Microbiology and Parasitology, University of Buea, P.B. 63 ,

Buea, Cameroon

Full list of author information is available at the end of the article
}

death attributed to malaria occurs in SSA, especially in children aged under 5 years [2]. Although there has been a recent decline in the incidence of malaria, it is still a major killer in children, claiming the life of a child every 2 min [1] in SSA.

In Cameroon, malaria is the major cause of morbidity and mortality among the most vulnerable groups including children aged under 5 years (18\%), pregnant women (5\%), people living with HIV/AIDS (5.5\%) and the poor $(40 \%)[3,4]$. In Cameroon, malaria accounts for $48 \%$ of all hospital admissions, $30 \%$ of morbidity and $67 \%$ of 
childhood mortality per year $[5,6]$. The epidemiology of malaria in Cameroon has been described as unique, having all the different epidemiological strata present in all of Africa [7, 8]. Six epidemiological strata have been identified and mapped in Cameroon, namely, the Sudanosahelian (SS) strata, High inland plateau (HIP) strata, Savannah-forest transmission (SF) strata, South Cameroon Equatorial forest (SCEF) strata, High western plateau altitude (HWP) strata and Coastal (C) strata [7]. These epidemiologic strata differ in terms of their geographical and ecological characteristics, transmission pattern and endemicity level and in terms of the main vectors transmitting malaria parasites [7].

Malaria is caused by parasitic protozoans of the genus Plasmodium. Five species of Plasmodia are known to cause disease in humans, namely, P. falciparum, P. ovale, P. malariae, $P$. vivax and $P$. knowlesi. The distribution of the different Plasmodia is not uniform throughout the world; P. vivax is more predominant in Asia [9] and $P$. falciparum in Africa [10]. Although P. falciparum is the most virulent species accounting for the majority of deaths [11], recent evidence suggest that $P$. vivax malaria is also associated with potentially life-threatening conditions about as often as with a diagnosis of $P$. falciparum infection [12]. In Cameroon, malaria was known to be caused solely by $P$. falciparum, but an increasing number of studies performed recently report other species of Plasmodia including $P$. vivax which is the second major species occurring as either single or mixed infection with P. falciparum $[13,14]$. P. malariae and P. ovale occur at a lower frequency and in most cases as mixed infection with P. falciparum [15-17]. P. knowlesi has not been reported to cause malaria in Cameroon. $P$. knowlesi which was only recently observed to cause human malaria [18] is the most common species today in certain areas of Southeast Asia [19]. Like P. vivax, P. knowlesi also requires the Duffy antigen for infection [20] and is therefore absent in populations lacking the Duffy antigen especially in SSA. Interestingly, $P$. vivax has been shown to infect some people lacking the Duffy antigen in Cameroon [13, 14]. With the increase in global travel, there is the possibility that $P$. knowlesi may as well evolve to infect Duffy-negative populations.

Studies to identify the Plasmodium species causing malaria in children in Cameroon are limited. With the increasing number of reports of malaria being caused by Plasmodium species other than falciparum in Cameroon, it is important to provide baseline data on the distribution of the different Plasmodium species associated with clinical malaria in children, which will inform control policies. This study was therefore designed to identify the Plasmodium species associated with clinical malaria in children residing in five epidemiological strata of malaria in Cameroon.

\section{Methods}

Study area

Five out of the six epidemiological strata of malaria in Cameroon were randomly selected for this study. Five study sites, each representing the epidemiological strata, were further selected and included: Maroua in the Sudano-sahelian (SS) strata, Ngaoundere in the High inland plateau (HIP) strata, Yaounde in the South Cameroonian Equatorial forest (SCEF) strata, Bamenda in the High western plateau (HWP) strata and Limbe in the Coastal (C) strata (Fig. 1). The characteristics of these epidemiological strata of malaria had previously been described [7].

\section{Study design and duration}

This study was a hospital-based cross-sectional study involving children who came to consult in the outpatient department (OPD)/emergency units of regional hospitals in the different study sites. Data was collected between May and November 2015 (to coincide with the rainy season during which transmission is highest), simultaneously in the different study sites.

\section{Sample size estimation}

The sample size was estimated using the following formula for sample size calculation as described by Swinscow [21];

$$
\begin{aligned}
& n=\frac{Z^{2} \times p(1-p)}{e^{2}} \\
& Z=1.96
\end{aligned}
$$

$p=$ prevalence of malaria in Cameroon which is $29 \%$ [22].

$$
\begin{aligned}
& e=\text { error rate }=0.05 \\
& n=\frac{1.96^{2} \times 0.29(1-0.29)}{0.05^{2}}=316.4 \approx 317
\end{aligned}
$$

Thus, we recruited 317 participants per study site giving an overall total of 1585 for the 5 sites.

\section{Study population}

Eligible participants were febrile children ( $\leq 15$ years) who were consecutively recruited as they came to consult in the OPD or emergency unit of the hospitals in the different study sites. Patients not on any antimalarial treatment for at least 1 week prior to the study commencing were included.

\section{Laboratory analyses \\ Specimen collection}

About $4 \mathrm{ml}$ of blood was collected from consented participants using aseptic techniques into EDTA test tubes. 


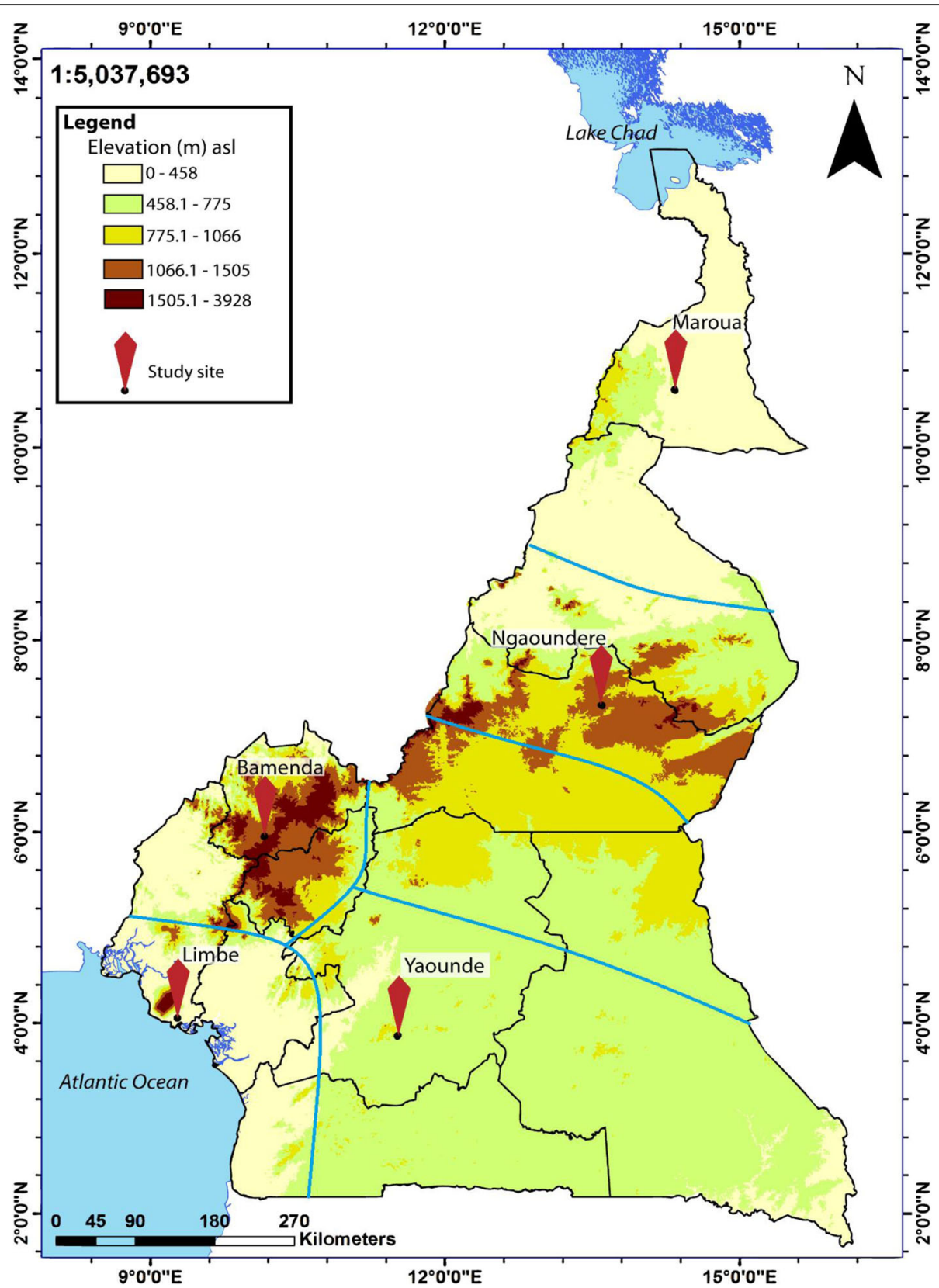

Fig. 1 Map depicting the study sites selected. Five epidemiological strata are delineated

The uncoagulated blood was used to perform complete blood count $(\mathrm{CBC})$ and prepare thick and thin films for malaria screening by microscopy and for the performance of polymerase chain reaction (PCR).

\section{Performance of complete blood count}

The CBC was performed using the Mindray Auto haematology analyzer (BC-2800, Shenzhen Mindray BioMedical Electronics Co., Ltd). The white blood cell (WBC) counts were obtained from the $\mathrm{CBC}$ results and used in the estimation of malaria parasite density.

\section{Microscopic detection of malaria parasite}

The prepared blood films were air-dried and stained with $10 \%$ Giemsa ( 1 in 20 dilutions) for $25-30$ min [23]. Blood films were read by two expert microscopists who were blinded from the results of the other. In case of any discrepancy with the results obtained by the two microscopists, a third was brought in and the results obtained were considered as final. Thick films were screened for at least 200 fields using a $\times 100$ (oil immersion) objective. If asexual stages of malaria parasites were seen, they were counted until 500WBC were 
reached. The slides were only declared negative after counting to $2500 \mathrm{WBC}$. Malaria parasite density was estimated by dividing the parasites counted by 500 and then multiplied by the WBC count of the participants to give numbers in parasite per microliter of blood [24].

\section{PCR detection of Plasmodium spp. in the blood DNA extraction}

The Chelex method [25] was used to extract DNA from the whole blood. Briefly, to $50 \mu \mathrm{l}$ of whole blood, $0.5 \mathrm{ml}$ of $\mathrm{RBC}$ lysis buffer $(0.2 \% \mathrm{NaCl}, 1 \%$ Triton $\mathrm{X}-100$ and 1 mM EDTA) was added and mixed by inverting. The tubes and their contents were centrifuged at $11300 \mathrm{rpm}$ for $10 \mathrm{~min}$, and the supernatants were discarded. Five hundred microliters of $1 \times$ PBS were again added to wash the pellets and centrifuged again. The supernatants were discarded, and $50 \mu \mathrm{l}$ of $20 \times$ Chelex and $150 \mu \mathrm{l}$ of distilled water were added to the pellets. The tubes were then incubated at $99{ }^{\circ} \mathrm{C}$ for $20 \mathrm{~min}$, centrifuged at maximum speed $(13,500 \mathrm{rpm})$ for $10 \mathrm{~min}$, and about $120 \mu \mathrm{l}$ of the supernatant was collected and stored as parasite genomic DNA at $-20{ }^{\circ} \mathrm{C}$ for future use.

\section{Amplification of Plasmodium DNA}

Genus- and species-specific sequences have been identified within the small subunit ribosomal DNA genes of all human malaria parasites ( $P$. falciparum, $P$. vivax, $P$. malariae, $P$. ovale and P. knowlesi). We used the Oligonucleotide primer pairs designed by Snounou et al. [26] and Padley et al. [27] in a multiplex PCR to detect P. falciparum, $P$. vivax, $P$. malariae and $P$. ovale in the host's total DNA. Reaction mix was made in a final volume of $12.5 \mu \mathrm{L}$ containing $6.25 \mu \mathrm{L}$ of $2 \times$ GoTaq $^{\circ}$ Hot Start Green master mix (Promega ${ }^{\circ}$, USA), $0.2 \mu \mathrm{M}$ of each primer (IDT ${ }^{\oplus}$, Iowa, USA), $3.25 \mu \mathrm{L}$ of molecular grade water (SigmaAldrich, Switzerland) and $2.5 \mu \mathrm{L}$ of DNA solution served as a template. Positive controls were included for all Plasmodium species. The cycling conditions were as follows: initial heating at $95{ }^{\circ} \mathrm{C}$ for $2 \mathrm{~min}, 43$ cycles of heating at $95{ }^{\circ} \mathrm{C}$ for $45 \mathrm{~s}$, annealing at $58{ }^{\circ} \mathrm{C}$ for $90 \mathrm{~s}$ and extension at $72{ }^{\circ} \mathrm{C}$ for $60 \mathrm{~s}$, and a final extension at $72^{\circ}$ $\mathrm{C}$ for $5 \mathrm{~min}$.

Amplification of P. knowlesi genomic DNA was done using the protocol described by Lucchi et al [28]. The reaction mix was made in a final volume of $25 \mu \mathrm{L}$ containing $12.5 \mu \mathrm{L}$ of $2 \times$ GoTaq $^{\oplus}$ Hot Start Green master mix (Promega ${ }^{\oplus}$, USA), $250 \mathrm{nM}$ each of the forward and reverse primers $\left(\right.$ IDT $^{\oplus}$, Iowa, USA), molecular grade water (SigmaAldrich, Switzerland) and $1 \mu \mathrm{L}$ of DNA as template. The cycling conditions were initial heating at $95{ }^{\circ} \mathrm{C}$ for $2 \mathrm{~min}, 35$ cycles of heating at $95{ }^{\circ} \mathrm{C}$ for $30 \mathrm{~s}$, annealing at $57{ }^{\circ} \mathrm{C}$ for $30 \mathrm{~s}$ and extension at $72{ }^{\circ} \mathrm{C}$ for $45 \mathrm{~s}$, and a final extension at $72{ }^{\circ} \mathrm{C}$ for $5 \mathrm{~min}$.
The PCR products were all analysed using $2 \%$ agarose gel electrophoresis, stained with ethidium bromide for fluorescence. The expected band sizes were $200 \mathrm{bp}$ for $P$. knowlesi, 395 bp for $P$. falciparum, 499 bp for $P$. vivax, $269 \mathrm{bp}$ for $P$. malariae and $436 \mathrm{bp}$ for $P$. ovale. The samples were ran against a 100-bp molecular weight marker.

\section{Data analysis}

Data collected were entered into an Excel spreadsheet and analysed using the Stata ${ }^{\oplus}$ version 12.1 software (StataCorp LP, Texas, USA). The statistical tests performed included the Pearson's chi-square test for comparison of proportions. Statistical significance was set at $p<0.05$.

\section{Results}

\section{Characteristics of the study population}

One thousand six hundred nine (1609) children met the inclusion criteria and were enrolled; 318, 318, 341, 315 and 317 were enrolled in Bamenda, Limbe, Maroua, Ngaoundere and Yaounde, respectively (Table 1). Among them were 779 (48.4\%) females and 830 (51.6\%) males. The ages of the participants ranged between 0 and 180 months (mean \pm SD $=63.65 \pm 56.69$ ).

\section{Prevalence of malaria in the study population}

Among the 1609 participants, 242 and 283 were positive for malaria parasites by Giemsa microscopy (GM) and PCR, respectively. A marginal difference was observed in the detection rate between GM and PCR $(p=0.05)$. However, GM demonstrated a high sensitivity (85.5\%) and specificity (100\%) and, overall, a perfectly correlated agreement with PCR (97.5\%) in the current study (Table 2). The PCR-adjusted prevalence was 17.6\% (95\% CI 15.8-19.5). The prevalence of malaria was highest in Limbe 29.9\% (95/318; 95\% CI 24.9-35.2) followed by Yaounde 21.9\% (75/341; 95\% CI 17.7-26.7), Bamenda $16.7 \%$ (53/318; 95\% CI 12.7-21.2) and Ngaoundere $10.7 \%(34 / 317$; 95\% CI 7.5-14.7) and lowest in Maroua $8.3 \%(26 / 315 ; 95 \%$ CI 5.5-11.9). There was a significant association between the malaria prevalence and study site $(p<0.001)$.

Overall, there was no significant association between the prevalence of malaria and gender $(p=0.239$, Table 3$)$.

Generally, the prevalence of malaria was highest in participants between 60 and 119 months and lowest in participants below 60 months (Table 3). A significant association was observed between the prevalence of malaria and age $(p<0.001)$.

All $(100 \%)$ the cases of malaria in this study were caused by $P$. falciparum as determined by the multiplex PCR and GM. Neither P. vivax, P. malariae, P. ovale nor $P$. knowlesi was identified. Furthermore, no mix infection with other Plasmodium species was observed. 
Table 1 Distribution of the study population with respect to age, gender and study site

\begin{tabular}{|c|c|c|c|c|c|c|c|}
\hline \multirow{2}{*}{$\begin{array}{l}\text { Epidemiological } \\
\text { strata }\end{array}$} & \multirow[t]{2}{*}{ Study sites } & & & \multicolumn{3}{|c|}{ Age (months) } & \multirow[t]{2}{*}{ Total } \\
\hline & & & & $<60$ & 60-119 & $120+$ & \\
\hline \multirow[t]{3}{*}{ HWP } & Bamenda & Gender & $\mathrm{F}$ & $70(40.5)$ & 29 (16.8) & $74(42.8)$ & $173(54.4)$ \\
\hline & & & M & $58(40.0)$ & $38(26.2)$ & 49 (33.8) & $145(45.6)$ \\
\hline & & Total & & $128(40.3)$ & $67(21.1)$ & $123(38.7)$ & 318 \\
\hline \multirow[t]{3}{*}{ C } & Limbe & Gender & $\mathrm{F}$ & $75(50.3)$ & $39(26.2)$ & $35(23.5)$ & $149(46.9)$ \\
\hline & & & M & $103(61.0)$ & 39 (23.1) & 27 (15.9) & $169(53.1)$ \\
\hline & & Total & & $178(56.0)$ & $78(24.5)$ & $62(19.5)$ & 318 \\
\hline \multirow[t]{3}{*}{ SCEF } & Yaounde & Gender & $\mathrm{F}$ & $61(40.7)$ & $32(21.3)$ & $57(38.0)$ & $150(44.0)$ \\
\hline & & & M & $100(52.4)$ & $46(24.1)$ & 45 (23.6) & $191(56.0)$ \\
\hline & & Total & & $161(47.2)$ & 78 (22.9) & $102(29.9)$ & 341 \\
\hline \multirow[t]{3}{*}{ SS } & Maroua & Gender & $\mathrm{F}$ & $122(74.4)$ & $27(16.5)$ & $15(9.1)$ & $164(52.1)$ \\
\hline & & & M & $111(73.5)$ & 27 (17.9) & $13(8.6)$ & $151(47.9)$ \\
\hline & & Total & & $233(74.0)$ & $54(17.1)$ & $28(8.9)$ & 315 \\
\hline \multirow[t]{3}{*}{ HIP } & Ngaoundere & Gender & $\mathrm{F}$ & $94(65.7)$ & $32(22.4)$ & 17 (11.9) & $143(45.1)$ \\
\hline & & & M & $116(66.7)$ & $34(19.5)$ & $24(13.8)$ & $174(54.9)$ \\
\hline & & Total & & $210(66.3)$ & $66(20.8)$ & $41(12.9)$ & 317 \\
\hline \multirow[t]{3}{*}{ Total } & & Gender & $\mathrm{F}$ & $422(54.2)$ & $159(20.4)$ & $198(25.4)$ & 779 (48.4) \\
\hline & & & M & 488 (58.8) & $184(22.2)$ & $158(19.0)$ & 830 (51.6) \\
\hline & & Total & & 910 (56.6) & 343 (21.3) & 356 (22.1) & 1609 \\
\hline
\end{tabular}

Data are presented as number (\%)

HWP High western plateau strata, C Coastal strata, SCEF South Cameroonian Equatorial strata, SS Sudano-sahelian strata, HIP High inland plateau strata, F female,

$M$ male

\section{Discussion}

In the current study, the overall prevalence of malaria was $17.6 \%$ as determined by PCR. This prevalence is however lower than the national prevalence of $29 \%$ reported in 2012 [22]. This difference could be attributed to the relentless efforts of Cameroon's government to control the disease through the mass distribution of insecticide-treated bed nets to all the households in the country and also to the intense sensitization of the population through media [29, 30]. The prevalence of malaria was highest in Limbe (in the C strata) and lowest in Maroua (in the SS strata). The decreasing trend observed in the prevalence of malaria from the South towards the North

Table 2 The performance of Giemsa microscopy (GM) in comparison to PCR in the detection of malaria parasites in the study population

\begin{tabular}{|c|c|c|c|c|}
\hline & & \multicolumn{3}{|l|}{ PCR } \\
\hline & & Positive & Negative & Total \\
\hline \multirow[t]{3}{*}{ Giemsa microscopy } & Positive & 242 & 0 & 242 \\
\hline & Negative & 41 & 1326 & 1367 \\
\hline & Total & 283 & 1326 & 1609 \\
\hline Sensitivity, \% (Cl) & $85.5(80.9-89.4)$ & & & \\
\hline Specificity, \% & 100 & & & \\
\hline Positive predictive value (PPV), \% & 100 & & & \\
\hline Negative predictive value (NPV), \% (Cl) & $97.0(96.0-97.8)$ & & & \\
\hline False positive rate (FPR), \% (CI) & $0.0(0.0-2.3)$ & & & \\
\hline False negative rate (FNR), \% (Cl) & $14.5(2.2-40.1)$ & & & \\
\hline Agreement between tests, \% (Cl) & $97.5(96.6-98.2)$ & & & \\
\hline
\end{tabular}

Sensitivity = [true positive/(true positive + false negative) $\times 100]$; specificity $=$ [true negative/(true negative + false positive) $\times 100 ;$ PPV $=$ [true positive $/($ true positive + false positive) $\times 100] ; \mathrm{NPV}=$ [true negative/(true negative + false negative) $\times 100] ;$ Agreement $=[$ true positive + true negative $/ \mathrm{N} \times 100] ; \mathrm{FPR}=1-$ specificity; FNR = 1 - sensitivity 
Table 3 Distribution of malaria in the study population stratified according to age, gender and study site

\begin{tabular}{|c|c|c|c|c|c|c|c|c|c|c|c|c|c|c|}
\hline \multirow[t]{3}{*}{ Study site } & \multicolumn{6}{|c|}{ Gender } & \multicolumn{8}{|c|}{ Age category (months) } \\
\hline & \multicolumn{2}{|c|}{ Female } & \multicolumn{2}{|l|}{ Male } & \multirow[t]{2}{*}{$x^{2}$} & \multirow[t]{2}{*}{$p$ value } & \multicolumn{2}{|c|}{$<60$} & \multicolumn{2}{|c|}{$60-119$} & \multicolumn{2}{|l|}{$120+$} & \multirow[t]{2}{*}{$x^{2}$} & \multirow[t]{2}{*}{$p$ value } \\
\hline & $n$ & Pos (\%) & $n$ & Pos (\%) & & & $n$ & Pos (\%) & $n$ & Pos (\%) & $n$ & Pos (\%) & & \\
\hline Bamenda & 173 & $34(19.7)$ & 145 & $19(13.1)$ & 2.436 & 0.119 & 128 & $16(12.5)$ & 67 & $16(23.9)$ & 123 & $21(17.1)$ & 4.125 & 0.127 \\
\hline Limbe & 149 & $48(32.2)$ & 169 & $47(27.8)$ & 0.733 & 0.392 & 178 & $46(25.8)$ & 78 & 34 (43.6) & 62 & $15(24.2)$ & 9.340 & 0.009 \\
\hline Yaounde & 150 & $32(21.3)$ & 191 & $43(22.5)$ & 0.068 & 0.794 & 161 & $32(19.9)$ & 78 & $23(29.5)$ & 102 & $20(19.6)$ & 3.312 & 0.191 \\
\hline Maroua & 164 & $15(9.2)$ & 151 & $11(7.3)$ & 0.360 & 0.549 & 232 & $19(8.2)$ & 54 & $5(9.3)$ & 28 & $2(7.1)$ & 0.121 & 0.941 \\
\hline Ngaoundere & 143 & $17(11.9)$ & 174 & $17(9.8)$ & 0.368 & 0.544 & 210 & $22(10.5)$ & 66 & $7(10.6)$ & 41 & $5(12.2)$ & 0.167 & 0.948 \\
\hline Total & 779 & $146(18.7)$ & 830 & $137(16.5)$ & 1.386 & 0.239 & 910 & $135(14.8)$ & 343 & $85(24.8)$ & 356 & $63(17.7)$ & 17.005 & $<0.001$ \\
\hline
\end{tabular}

of the country could be attributed to the geographical setting; transmission of malaria has been described as hyperendemic in Limbe [31], holoendemic in Yaounde [30, 32], mesoendemic in Bamenda and Ngaoundere and hypoendemic in Maroua. The prevalence of malaria did not differ between males and females, which is consistent with other studies $[4,22,33-36]$. On the other hand, the prevalence of malaria was significantly higher in children between 60 and 119 months of age and this is consistent with some other studies [33, 37, 38]. The higher prevalence of malaria in children between 60 and 119 months could be attributed to their playful attitude as they grow up which exposes them to infective bites of the Anopheles mosquitoes. The observation of a significant association between the prevalence of malaria and age in the current study is however contrary to some studies that found no association of malaria with age [26-34].

In the current study, P. falciparum was the only parasite species identified. This is reminiscent of the WHO report that all (100\%) of malaria cases in Cameroon are caused by $P$. falciparum [39]. It is also consistent with studies which show that $P$. falciparum was associated with all the cases of clinical malaria in the country [15-17]. The finding is however contradictory to studies that have reported prevalences of $P$. vivax ranging from $4 \%$ [14] to 14.9\% [13]. The difference between these studies and ours could be attributed to differences in the study design; our study targeted children presenting with symptoms of malaria meanwhile theirs targeted both symptomatic or asymptomatic adults and children. In addition, the differences in the respective study locations could account for the differences in the results obtained. Furthermore, no mixed infection was detected in the current study, which is contrary to other studies that have reported low prevalence of mixed infection between $P$. falciparum and $P$. malariae or $P$. ovale [15-17]. The difference between these studies and ours could also be attributed to the study design; Giemsa microscopy was the tool used to identify the different species of Plasmodia which is subject to errors especially when not done by experts [40, 41]; meanwhile, in our study, PCR was used. The high sensitivity of PCR is further demonstrated in this study as the detection rate was significantly higher with PCR compared to that with microscopy. This discrepancy could stem from differences in the detection limits of microscopy and PCR; microscopy has a detection limit of 50-100 parasites/ $\mu$; meanwhile, PCR has a detection limit as low as $1-5$ parasites/ $\mu l[42,43]$. PCR has the added advantage of accurately detecting the different plasmodia species $[42,44,45]$. However, GM in the current study demonstrated a perfectly correlated agreement with PCR (97.5\%). In the current study, $P$. falciparum was correctly identified as the only Plasmodium species by GM and this confirms the high specificity of GM in the identification of the different Plasmodia. One limitation of using PCR in the diagnosis of malaria is that the parasite DNA can remain in the blood stream long after the infection has been cleared and therefore differentiating an active infection from a recently cleared infection poses a challenge [46]. As a consequence, microscopy still remains the gold standard [41, 47, 48]. In the current study, no infection with $P$. knowlesi was observed. Being one of the first studies to target $P$. knowlesi in the country serves as a confirmation of its absence.

In this study, data was collected only during the rainy season during which transmission is usually at its peak. This may have affected the distribution of the different Plasmodia. Studies designed to collect data in both the rainy and the dry season will be paramount to providing a clearer picture of the distribution of the Plasmodia with season. More so, in the current study, participants were recruited only from health care facilities in urban settings and the data generated may therefore not be generalisable to children living in rural areas. Studies will also be needed in rural areas to give a clearer picture. 


\section{Conclusions}

A malaria prevalence of $17.6 \%$ was observed in the target population. The prevalence was significantly higher in children between 60 and 119 months. On the contrary, gender had no influence on malaria prevalence. A significant association was also observed between the prevalence of malaria and the geographical setting, being highest in Limbe (in the $\mathrm{C}$ strata) and lowest in Maroua (in the SS strata). P. falciparum was the only species associated with clinical malaria in the target population, and no mixed infection with other Plasmodium species was identified, which is contrary to earlier studies.

\section{Abbreviations}

C: Coastal strata; FNR: False negative rate; FPR: False positive rate; GM: Giemsa microscopy; HIP: High inland plateau strata; HWP: High western plateau strata; NPV: Negative predictive value; P: Plasmodium; PCR: Polymerase chain reaction; PPV: Positive predictive value; SCEF: South Cameroonian Equatorial strata; SS: Sudano-sahelian strata

\section{Acknowledgements}

The authors wish to thank the directors, doctors, nurses and the laboratory staff of the regional hospitals of Limbe, Bamenda, Yaounde, Ngaoundere and Maroua for allowing us to use their patients and for their help in the data collection. Our sincere gratitude also goes to the parents or guardians who consented for their children to take part in this study.

\section{Funding}

Not applicable.

\section{Availability of data and materials}

All the data supporting our finding has been presented in the manuscript.

\section{Author's contribution}

TEK conceived the study; participated in its design, coordination and data collection; took part in the analyses and interpretation; conducted literature search and review; performed the statistical analysis and co-wrote the first draft. LAN and TN conceived, designed and coordinated the study; participated in the statistical analysis; and critically revised the manuscript. AL took part in the analyses and interpretation and critically revised the manuscript. TDBK and KAT participated in the data collection, took part in the analyses and interpretation, conducted the literature search and review and co-wrote the first draft. All authors read and approved the final manuscript

\section{Competing interests}

The authors declare that they have no competing interests.

\section{Consent for publication}

Not applicable.

\section{Ethics approval and consent to participate}

The study protocol was approved by the National Ethics Committee of Research for Human Health no 2014/12/518/CE/CNERSH/SP. Administrative clearance was obtained from the directors of the various hospitals used for this study. Written informed consent was obtained from the parents or guardians of the children prior to participation in this study.

\section{Publisher's Note}

Springer Nature remains neutral with regard to jurisdictional claims in published maps and institutional affiliations.

\section{Author details}

${ }^{1}$ Department of Medical Laboratory Sciences, University of Buea, P.B. 63, Buea, Cameroon. ${ }^{2}$ Department of Microbiology and Parasitology, University of Buea, P.B. 63, Buea, Cameroon. '3Diagnostic laboratory, Regional Hospital of Buea, P.B. 32, Buea, Cameroon. ${ }^{4}$ Research and Development Department, NovaTec Immundiagnostica GmbH, Dietzenbach, Germany.
Received: 31 March 2017 Accepted: 16 May 2017

Published online: 15 June 2017

\section{References}

1. World Health Organisation. World malaria report 2015. Geneva: World Health Organisation; 2015. http://apps.who.int/iris/bitstream/10665/200018/ 1/9789241565158_eng.pdf.

2. World Health Organisation. World malaria report 2014. Geneva: World Health Organisation; 2014. http://www.who.int/malaria/publications/world_ malaria_report_2014/wmr-2014-no-profiles.pdf.

3. Bigoga JD, Manga L, Titanji VPK, Coetzee M, Leke RGF. Malaria vectors and transmission dynamics in coastal south-western Cameroon. Malar J. 2007;6:5.

4. Ndong IC, van Reenen M, Boakye DA, Mbacham WF, Grobler AF. Trends in malaria admissions at the Mbakong Health Centre of the North West Region of Cameroon: a retrospective study. Malar J. 2014;13:328.

5. World Health Organisation. The world malaria report 2011. Geneva: World Health Organization; 2011. http://apps.who.int/iris/bitstream/10665/44792/2/ 9789241564403_eng_full.pdf.

6. Antonio-Nkondjio C, Demanou M, Etang J, Bouchite B. Impact of cyfluthrin (Solfac EW050) impregnated bed nets on malaria transmission in the city of Mbandjock: lessons for the nationwide distribution of long-lasting insecticidal nets (LLINs) in Cameroon. Parasites Vectors. 2013:6:10.

7. Ministry of Public Health. National Malaria Control Programme Report. 2008, Republic of Cameroon, http://www.who.int/alliance-hpsr/projects/alliancehpsr policybriefscalingupmalariacameroon.pdf. Accessed 19 May 2017.

8. Ngassa HGM, Awasthi G, Singh PK, Gouado I, Das A. Does malaria epidemiology project Cameroon as 'Africa in miniature'? J Biosci. 2014;39(4):727-38.

9. Arnott A, Barry AE, Reeder JC. Understanding the population genetics of Plasmodium vivax is essential for malaria control and elimination. Malar J. 2012;11:14.

10. Collins WE. Plasmodium knowlesi: a malaria parasite of monkeys and humans. Annu Rev Entomol. 2012;57:107-21.

11. Sarkar PK, Ahluwalia G, Vijayan VK, Talwar A. Critical care aspects of malaria. J Intensive Care Med. 2009;25(2):93-103.

12. Baird JK. Evidence and implications of mortality associated with acute Plasmodium vivax malaria. Clin Microbiol Rev. 2013;26(1):36-57.

13. Fru-Cho J, Bumah W, Safeukui I, Nkuo-Akenji T, Titanji VPK, Haldar K. Molecular typing reveals substantial Plasmodium vivax infection in asymptomatic adults in a rural area of Cameroon. Malar J. 2014;13:170.

14. Ngassa Mbenda HG, Das A. Molecular evidence of Plasmodium vivax mono and mixed malaria parasite infections in Duffy-negative native Cameroonians. PLoS ONE. 2014;9(8):e103262.

15. Quakyi IA, Leke RGF, Befidi-Mengue R, Tsafack M, Bomba-Nkolo D, Manga L, et al. The epidemiology of plasmodium falciparum malaria in two Cameroonian villages: Simbok and Etoa. Am J Trop Med Hyg. 2000;63(5, 6):222-30.

16. Payne VK, Fusi-Ngwa CK, Ndambi E, Mpoame M. Plasmodium index prevention, and control of malaria in Dschang municipality, Cameroon. Ann Trop Med Public Health. 2013:6:166-72.

17. Kwenti TE, Nkume FA, Tanjeko AT, Kwenti TDB. The effect of intestinal parasitic infection on the clinical outcome of malaria in coinfected children in Cameroon. PLoS Negl Trop Dis. 2016;10(4):e0004673. doi:10.1371/journal. pntd.0004673.

18. Chin W, Contacos PG, Coatney RG, Kimbal HR. A naturally acquired quotidian-type malaria in man transferable to monkeys. Science. 1965; 149(3686):865

19. McCutchan TF, Piper RC, Makler MT. Use of malaria rapid diagnostic test to identify Plasmodium knowlesi infection. Emerg Infect Dis. 2008;14(11):1750-2.

20. Barber BE, William T, Jikal M, Jilip J, Dhararaj P, Menon J, et al. Plasmodium knowlesi malaria in children. Emerg Infect Dis. 2011:17(5):814-20.

21. Swinscow TDV, Campbell MJ. Statistics at Square 10th edition. London: BMJ books: 2002.

22. Mangham LJ, Cundill B, Achonduh OA, Ambebila JN, Lele AK, Metoh TN, et al. Malaria prevalence and treatment of febrile patients at health facilities and medicine retailers in Cameroon. Trop Med Int Health. 2012;17(3):330-42.

23. Njunda AL, Assob NJC, Nsagha SD, Kamga FHL, Mokenyu MD, Kwenti ET. Comparison of capillary and venous blood using blood film microscopy in the detection of malaria parasites: a hospital based study. Sci J Microbiol. 2013;2(5):89-94.

24. Research Malaria Microscopy Standards Working Group. Microscopy for the detection, identification and quantification of malaria parasites on stained thick and thin films. Geneva: World Health Organization; 2015. p. 25. 
25. Musapa M, Kumwenda T, Mkulama M, Chishimba S, Norris DE, Thuma PE, et al. A simple Chelex protocol for DNA extraction from Anopheles spp. J Vis Exp. 2013;71:3281.

26. Snounou G, Pinheiro L, Goncalves A, Fonseca L, Dias F, Brown KN, et al. The importance of sensitive detection of malaria parasites in the human and insect hosts in epidemiological studies, as shown by the analysis of field samples from Guinea Bissau. Trans R Soc Trop Med Hyg. 1993;87:649-53.

27. Padley D, Moody AH, Chiodini PL, Saldanha J. Use of a rapid, single-round, multiplex PCR to detect malarial parasites and identify the species present. Ann Trop Med Parasitol. 2003;97:131-7.

28. Lucchi NW, Poorak M, Oberstaller J, DeBarry J, Srinivasamoorthy G, Goldman I, et al. A new single-step PCR assay for the detection of the zoonotic malaria parasite Plasmodium knowlesi. PloS ONE. 2012;7(2):e31848.

29. Sumbele IUN, Ning TR, Bopda OSM, Nkuo-Akenji T. Variation in malariometric and red cell indices in children in the Mount Cameroon area following enhanced malaria control measures: evidence from a repeated cross-sectional study. Malar J. 2014;13:334.

30. Njunda AL, Njumkeng C, Nsagha SD, Assob JCN, Kwenti ET. The prevalence of malaria in people living with HIV in Yaounde, Cameroon. BMC Public Health. 2016;16:964.

31. Achidi EA, Apinjoh TO, Anchang-Kimbi JK, Mugri RN, Ngwai AN, Yafi CN. Severe and uncomplicated falciparum malaria in children from three regions and three ethnic groups in Cameroon: prospective study. Malar J. 2012;11:215

32. Craig M, Snow R, le Sueur D. A climate-based distribution model of malaria transmission in sub-Saharan Africa. Parasitol Today. 1999;15(3):105-11.

33. Degarege A, Legesse M, Medhin G, Animut A, Erko B. Malaria and related outcomes in patients with intestinal helminths: a cross-sectional study. BMC Infect Dis. 2012;12:291.

34. Tchinda VHM, Ponka R, Ndzi ES, Madocgne AK, Amédée M, Tchinda MG, et al. Prevalence of malaria and soil-transmitted helminth infections and their association with undernutrition in schoolchildren residing in Mfou health district in Cameroon. J Public Health Epidemiol. 2012;4(9):253-60.

35. Kinung'hi SM, Magnussen P, Kaatano GM, Kishamawe C, Vennervald BJ. Malaria and Helminth co-infections in school and preschool children: a cross-sectional study in Magu District, North-Western Tanzania. PLoS ONE. 2014;9(1):e86510

36. Njunda AL, Fon SG, Assob JCN, Nsagha DS, Kwenti TDB, Kwenti ET. Malaria and intestinal parasitic coinfection and their contribution to anaemia in children in Cameroon. Infect Dis Poverty. 2015;4:43.

37. Alemu A, Shiferaw Y, Ambachew A, Hamid H. Malaria helminth co-infections and their contribution for anaemia in febrile patients attending Azzezo health center, Gondar, Northwest Ethiopia: a cross sectional study. Asian Pac J Trop Med. 2012;5:803-9.

38. Sumbele IUN, Kimbi HK, Ndamukong-Nyanga JL, Nweboh M, AnchangKimbi JK, Lum E, et al. Malarial anaemia and anaemia severity in apparently healthy primary school children in urban and rural settings in the Mount Cameroon area: cross sectional survey. PLoS ONE. 2015;10(4):e0123549.

39. World Health Organisation. Cameroon: epidemiological profile. Geneva: World Health organisation; 2015. http://www.who.int/malaria/publications/ country-profiles/profile_cmr_en.pdf

40. Moody A. Rapid diagnostic tests for malaria parasites. Clin Microbiol Rev. 2002;15:66.

41. Wongsrichanalai C, Barcus MJ, Muth S, Sutamihardja A, Wernsdorfer WH. A review of malaria diagnostic tools: microscopy and rapid diagnostic test (RDT). Am J Trop Med Hyg. 2007;77(6):119-27.

42. Swan H, Sloan L, Muyombwe A, Chavalitshewinkoon-Petmitr P, Krudsood S, Leowattana W, et al. Evaluation of a real-time polymerase chain reaction assay for the diagnosis of malaria in patients from Thailand. Am J Trop Med Hyg. 2005;73:850-4.

43. Hawkes M, Kain KC. Advance in malaria diagnosis. Expert Rev Anti Infect Ther. 2007;5:1-11.

44. Mens PF, Schoone GJ, Kager PA, Schallig HD. Detection and identification of human Plasmodium species with real time quantitative nucleic acid sequence based amplification. Malar J. 2006;5:80

45. Mlambo G, Vasquez Y, LeBlanc R, Sullivan D, Kumar N. A filter paper method for the detection of Plasmodium falciparum gametocytes by reverse transcription polymerase chain reaction. Am J Trop Med Hyg. 2008;78:114-6.

46. Thongdee P, Chaijaroenkul W, Kuesap J, Na-Bangchang K. Nested-PCR and a new ELISA-based NovaLisa Test Kit for malaria diagnosis in an endemic area of Thailand. Korean J Parasitol. 2014;52(4):377-81.
47. Coleman RE, Sattabongkot J, Promstaporm S, Maneechai N, Tippayachai B, Kengluecha A, et al. Comparison of PCR and microscopy for the detection of asymptomatic malaria in a Plasmodium falciparum/vivax endemic area in Thailand. Malar J. 2006:5:121-7.

48. Njunda AL, Nsagha DS, Assob NJC, Kwenti TDB, Nfor LG, Kwenti ET. Comparing the buffy coat and traditional blood smears in the microscopic diagnosis of malaria. Int J Malaria Res Rev. 2014;2(2):7-12.

\section{Submit your next manuscript to BioMed Central and we will help you at every step:}

- We accept pre-submission inquiries

- Our selector tool helps you to find the most relevant journal

- We provide round the clock customer support

- Convenient online submission

- Thorough peer review

- Inclusion in PubMed and all major indexing services

- Maximum visibility for your research

Submit your manuscript at www.biomedcentral.com/submit
Biomed Central 